GLOBAL JOURNAL OF AGRICULTURAL SCIENCES VOL. 17, 2018: 71-74

COPYRIGHT@ BACHUDO SCIENCE CO. LTD PRINTED IN NIGERIA ISSN 1596-2903 www.globaljournalseries.com, Email: info@globaljournalseries.com

\title{
STRATEGIES FOR THE MANAGEMENT OF ENVIRONMENTAL HAZARDS: IMPLICATIONS FOR SUSTAINABLE HEALTHY LIVING IN CALABAR URBAN, CROSS RIVER STATE, NIGERIA
}

\author{
OGBONNA, KALU IROHA AND BISONG, THERESA LARRY
}

(Received 28 May 2018; Revision Accepted 23 August 2018)

\begin{abstract}
The study was designed to asses the strategies adopted in the management of environmental hazards in Calabar urban. The specific objectives of the study were to identify the strategies adopted by the government to promote environmental management consciousness and prevention of environmental hazards as well as the role of the residents on environmental hazards prevention. Calabar urban comprises of two local government areas which include; Calabar municipality and Calabar south. A total of one hundred and twenty respondents were randomly selected from the study area. Also interview were conducted on staff of the ministry of environment, Calabar Urban Development Agency (CUDA) and Cross River Waste Management Agency (CRWMA). A structured questionnaire and interview guide were the instruments used to collect data for the study. Data for the study were analyzed using simple statistical tools such as frequency distribution tables and percentages. The results revealed that certain strategies were adopted by both government and agencies in reaching people with information on environmental issues. Some of the strategies include distribution of waste disposal materials $(75 \%)$, use of radio, television jingles $(60 \%)$, provision of designated dumping sites, daily sweeping and excavating of waste were identified as the most important strategies for prevention and management of environmental hazards. The study therefore recommended that government should extend its environmental management programmes beyond certain areas in Calabar urban to other remote streets in Calabar urban through the provision of accessible roads and good drainage channels to ensure effective environmental hazards prevention. Also that awareness campaigns should be increased to enlighten the public of their role in the prevention of environmental hazards, and environmental education be included in the curriculum of secondary schools to inculcate good environmental management attitude among young people.
\end{abstract}

KEYWORDS: Environmental hazards and sustainable healthy living

\section{INTRODUCTION}

Environmental hazards are global problems that exert tremendous influence on the sustainability and healthy living of human beings with various manifestations. Existence of uncertainties is part of living in all places and around the world. Healthy living is of great relevance as far as man exists (Cunninham and Saigo 2003). This is to say that an environmental determinant of health is fundamental in the effectiveness of the advancement of technology in the world at large.

Environmental pollution not only leads to deteriorating environmental conditions but have adverse effects on the health of people. According to the world development indicator report (WHO 1999), one and half billion people live a life exposed to dangerous levels of pollution, one billion live without clean water while two billion live without good sanitation. Also increase in population has been identified as exerting major influences on environment.

Nortstorm (2001) observed that the environment influences health profoundly, and as such, nearly one third of death and diseases in the world's least developed regions are due to environmental causes. Thus hazards present themselves to us in various manners through the air, water, land etc. and other natural resources (www.toolingu.com, 2009), Millions of people especially in low-income and informal settlements (Slums) as well as urban areas face varying health challenges. Today the health of most people all over the world is being threatened by a variety of diseases such as malaria and measles etc, influenced by social and environmental determinants. These in turn causes increased mortality rates in the society (Murray, 2004).

A comparative study of urban areas carried out by Timaeus and Lush (1995) clearly indicates that children's and adults health is affected by environmental conditions and economic status of the household. According to the study, people from better-off households have lower diarrhea mobility and mortality. Jacob and Wang (2003) projected that low quality and lack of access to clean water in the country side are the key factors affecting children's health. Therefore access to safe drinking water should be considered in urban

OGBONNA, KALU IROHA, Departmnet of Agricultural Extension and Rural Sociology university of Calabar, Calabar Nigeria BISONG, THERESA LARRY, Departmnet of Education, Cross River State College of Education, Akamkpa CRS Nigeria 
areas so that child mortality would be reduced.

Kamat (2000) conducted a pollution related study among people in urban areas to evaluate the full extent of the correlation between air pollution and damage to human health. According to the study 1000 deaths were directly attributed to out door air pollution in urban areas, while indoor air pollution was responsible for 200 deaths in cities (WHO, 1999). Water pollution from domestic and human waste is the main cause of much severe waterborne diseases, messy environment and obnoxious odours. The industrial water pollution is due to inadequate measures adopted in the industries for the abatement of pollution. Inadequate disposal of urban waste and open dumping of garbage contaminates surface and ground water (Ekpoh, 2003).

Adepoju (2014) have observed that water and sanitation services are basic necessities of conditions for development as they play important roles in improving health and quality of life. World Health Organization (WHO, 1999) estimated that $80 \%$ of the diseases in the world are associated with water usage or poor environmental hygiene. Cunnigham and Saigo (2003) noted that increasing river water pollution is the biggest threat to public health. The diseases commonly ceased due to polluted water are cholera, diarrhea, hepatitis, typhoid and guinea worm; whereas scabies, leprosy, trachoma and conjunctivitis are some of the diseases association with water scarcity. All these could be attributed to the rapidly increasing population and lack of water resources, inadequate access to safe drinking water and sanitation facilities.

Anon (2003) observed that air pollution is mainly caused by emissions from motor vehicles, especially diesel driven vehicles and power plants. Most epidemiological studies on the effects of air pollution conducted so far consistently observed adverse health outcomes at the concentrations of air pollutants in the atmosphere. A study by Environmental Protection Agency on the causes of indoor air pollution revealed that tobacco smoke from a cigarette when exhaled by the smoker is a major indoor air pollutant which could lead to health problems, such as irritation to mucous membrane in the eyes, nose and throat, chronic respiratory system infections such as cough and wheeze, all due to nicotine content in cigarette (Cunjingham and Saigo, 2003).

Some of the strategies for the management of environmental hazards include, sanitary landfill which is a disposal method whereby refuge is placed in trenches, abandoned mines or quarry sites that have been properly designed for this purpose. Deposited wastes are usually spread and covered with a required quantity of earth which are also spread and compacted after each day. In order not to let sanitary landfill look like an open dump, it needs to be strictly monitored scientifically in order to meet the oratorio for eliminating or diminishing environmental nuisance such as odour, flies, insects, wind blown litters etc, this involves the full utilization of available void space by good compaction of waste, and re-use of the reclaimed land for specific purpose (Baker, 1996).

Also, the removal of structures that obstruct the free passage of rain water to empty not into rivers or sea but into a central trough specifically constructed to recycle rain water from sewage and public drains will go a long way to reduce pollution. The waste content of the trough would be regulated from time to time and its sediments treated (Nigeria Environmental Study Action Team, 2000). Other environmental hazard management strategies as identified by Abumere (2002) include; improving access to clean water, raising sanitary standards, increasing building safety and reducing use of pollution fuels. In Calabar Urban, the Government of Cross River State is committed to ensuring proper disposal of waste through efforts such as provision of refuse dump stands, sweeping of the street, etc. It is against this background that this study became necessary to assess the strategies of managing environmental hazards in Calabar urban of Cross River State.

\section{OBJECTIVES OF THE STUDY}

The general objective of this study is to assess the strategies for managing environmental hazards and the implications for healthy living in Calabar Urban. The specific objectives includes:

i. $\quad$ identify the strategies for environmental hazards management employed by the government in the study area.

ii. identify the strategies used by the residents to manage environmental hazards in the study area.

iii. ascertain the strategies adopted by the Government to prevent environmental hazards in the study area.

\section{METHODOLOGY}

The study was carried out in Calabar urban which is the state capital of Cross River State and the city is best known for it's environmental cleanliness. Calabar records heavy rainfall during the wet season (April - November). The favourable climate of tropical humid, dry and wet seasons give rise to rich cultural lands, this encourages both perennial and annual crops cultivation.

Calabar urban comprises of two Local Government Areas; Calabar municipality and Calabar south. The study adopted the political delineation, and according to the political stratification, Calabar municipality and Calabar south are made up of ten (10) political wards each, making a total of twenty political wards. Five (5) wards each were randomly selected from Calabar municipality and Calabar south, respectively. A total of ten (10) wards were sampled from twenty (20) wards that make up the study area. From each of the selected wards, twelve (12) residents were randomly selected from both Calabar municipality and Calabar south, making a total sample size of 120 respondents.

To obtain data for the study, a structured questionnaire was developed based on the study objectives which was administered to the respondents by the researcher and retrieved by the researcher. Also an interview schedule was developed to elicit information from staff of Calabar urban development Authority (CUDA), Cross River State Ministry of Environment (CRSME) and the Calabar Waste Management Agency respectively. Data collection instruments were administered and retrieved by the researcher within a period of three weeks. Frequency 
distribution tables and percentages were used to analyze the data for this study.

RESULTS AND DISCUSSION
TABLE 1
Distribution of respondents based on strategies adopted by the government to promote environmental
management consciousness
\begin{tabular}{|l|l|l|l|}
\hline S/N & INFORMATION ON ENVIRONMENTAL MATTERS & NUMBER( ${ }^{*}$ ) & PERCENTAGE \\
\hline a & Provision of waste disposal materials & 86 & 71.7 \\
\hline b & Regular workshops, seminars, trainings of residents & 41 & 34.2 \\
\hline c & Use of radios, television, giggles/announcement & 72 & 60.00 \\
\hline d & Publication of environmental issues or newspaper & 38 & 31.7 \\
\hline e & Production and distribution of handbills leaflets & 96 & 80 \\
\hline
\end{tabular}

Multiple responses

Source: Field Survey, 2010

The study investigated the strategies adopted by the government to promote environmental management consciousness on the residents of the study area. Data in table 1 shows that distribution of wastes disposal materials $(71.7 \%)$, use of radio and television announcement $(60.00 \%)$, production and distribution of handbills/leaflets $(80 \%)$ have been the main strategies implored by the government in promoting environmental hazards consciousness and their management among the residents of the area. However organizing regular workshops, seminars and training programmes, as well as publication on environmental matters $(31.7 \%)$ were not found by the residents as very effective means of managing environmental hazards. This could be attributed to non readiness of the people, inability to purchase published materials and lack of awareness of workshops and seminar organized. This finding agree with that of Abumere (2002), who identified environmental management strategies to include provision of clean water, raising sanitary standards and reduce the use of pollution fuels.

TABLE 2

Strategies for prevention of environmental hazards

\begin{tabular}{|l|l|}
\hline S/N & STEPS TAKEN BY GOVERNMENT \\
\hline a) & Formation of laws on deforestation, illegal construction of structures, dumping of wastes \\
\hline b) & Ban on importation of toxic materials substances \\
\hline c) & Provision of designated dumping sites \\
\hline d) & Daily sweeping of areas and markets \\
\hline e) & Daily excavation of wastes \\
\hline f) & Distribution of wastes bins at home, offices, shops, schools \\
\hline g) & Construction of drainages, waterways, culverts \\
\hline h) & Ban on illegal excavation of sand for building \\
\hline i) & Removal of broken down vehicles and machines on the roads \\
\hline j) & Imprisonment of environmental hazard offenders \\
\hline
\end{tabular}

Multiple responses

Source: Field Survey, 2010

The study investigated strategies adopted for the prevention and management of environmental hazards from the point of view of government and agencies engaged in environmental hazards issues. Based on the result of the interview conducted, data in table 2 revealed that formulation of laws on deforestation, illegal construction of structures, dumping of wastes, daily sweeping and excavation of wastes and distribution of wastes bin at home, offices, markets, schools and public places were strategies adopted by government and its agencies towards the prevention of the occurrence of environmental hazards. Other strategies include, ban on

importation of materials considered toxic into the air, ban on illegal excavation of natural resources like sand for construction purposes, and imprisonment terms for offenders of environmental management.

This result is an indication of high level of awareness on the causes of environmental hazards and how to prevent their occurrence. Accordingly, NEST (2000) affirms that the removal of structures that obstruct the free passage of rain water to empty into rivers or sea but into a central trough will go a long way to prevent environmental

hazards

\section{TABLE 3}

Distribution of respondents based on perceived role of residents on environmental hazards prevention ROLE OF RESIDENTS ON HAZARD PREVENTION

\begin{tabular}{|l|l}
\hline ROLE OF RESIDENTS ON HAZARD PREVENTION & PReck ages \\
\hline Opening of block & 6 \\
\hline Regular payment of sanitary tariff & \\
\hline Planting of trees & 1 \\
\hline Provision of sanitary facilities (e.g toilets) in households & \\
\hline Daly excavation of wastes to dumping sites & 8 \\
\hline Preventing of sand/soil excavation & \\
\hline Clearing of nearby bushes/farms &
\end{tabular}

\begin{tabular}{|l|l|}
\hline NUMBER $\left(^{*}\right)$ & PERCENTAGE \\
\hline 100 & 83.3 \\
\hline 69 & \\
\hline 43 & 35.8 \\
\hline 90 & 75 \\
\hline 120 & 100 \\
\hline 20 & 16.7 \\
\hline 87 & 72.5 \\
\hline
\end{tabular}

Multiple responses

Source: Field Survey, 2010 
Data in table 3 indicates that daily excavation of wastes to dumpsite (100\%), opening of blocked culverts/drainages near residential houses to check flooding (83.3), and regular payment of sanitation fees/levies were identified as the major environmental hazard prevention activities that have been carried out by residents in the area surveyed to check environmental hazards. Other preventive activities of residents against environmental hazards include: clearing of nearby bushes $(72.5 \%)$, provision of sanitary facilities such as toilets in residential places $(75 \%)$, it could be concluded that residents in Calabar urban play significant roles in the prevention of environmental hazards.

\section{CONCLUSION}

The greatest environmental threats tend to be those closest to home as many people live in situations that impede their health through steady exposure to biological pathogens and chemical contaminations in their immediate environment. Many live without adequate shelter or in unacceptable housing, and others lacking access to safe water, and adequate sanitation, all of which are essential for good hygiene. The most important strategy to put forward in finding a lasting solution to the problems of environmental hazards is by making the population aware of the danger arising from indiscriminate dumping of pollutants. It is therefore necessary to create awareness through real-life education aiming at reaching every individual, including the lowest level of illiterate.

\section{RECOMMENDATIONS}

i. The government and other environmental agencies should increase awareness campaign through the various available communication media.

ii. The government through the ministry of education should include the teaching of environmental education in the curriculum of secondary schools to enable the young ones grow with a good environmental sanitation attitude.

iii. Laws on indiscriminate dumping of refuge should be enacted and enforced and culprits be prosecuted appropriately as this will serve as a deterrent to others.

iv. Structure that are obstructing drainage channels should be removed or reconstructed to make for easy passage of rain water.

\section{REFERENCES}

Abumere, P.P., 2002: Aspect of solid waste Disposal; U.S Geological survey circular

Adepoju W., 2014 Environmental sanitation: personal hygiene prevent epidemic out brake: The Nation newspaper April 2014
Anon, I.I.G., 2003, Evaluating pollution potentials of land based waste disposal; Santa Clara Country, Califonia, U.S.A

Baker, D., 1996: Wastes Management Planning Evaluation, Oxford University Press, London

Cunningham, U.P \& Cunningham, M.A., 2002: Principles of Environmental Science inquiry and applications. McGraw-Hill Publishers Boston, New York

Cunningham U.P \& Saigo, B.W., 2003; Environmental Science; A global concern,. McGraw-Hill publishers, Boston. New York

Ekpoh, R.A., 2003: Environmental waste and management: Ushie Printers and Publishers Company Ltd, Calabar, Nigeria.

Ekpoh, I.J, Ekpoh, U.I. \& Bassey N.U., 2008. The Role of Environmental Education and public enlightenment in urban waste management in Calabar, Cross River State, Nigeria; African Journal of Environmental Pollution and Health, 6(1) $7-12$

Jacob A.I \& Wang, C.I., 2003: The limited war on Water Pollution, In Man's Impact on Environment, Edited by T.R Detwyler; McGraw -Hill Book Company, New York.

Kamat S.B., 2000: Automotive option and quality management in developing countries; united Nations Environmental programme; Industry and Environmental Journal, 16(1) 1-12

Nigerian Environmental Study Action Team (NEST) (2000), Environmental impact assessment and environmental evaluation report.

Nortstorm D.E., 2001: Urban Planning and urban problems in United States of America. U.K.

Murray, C.J.L., 2004 Occupational Health and Safety in the African Region: Situation analysis and perspective report of the regional director; Regional committee for Africa, (AFR) RC54 (13)

World Health Organization (WHO) (1999): Air Quality Guidelines for particulate Matter; Ozone Nitrogen Dioxide and Sulphur Dioxide - Global update

Timaeus I.M \& Lush, L., 1995 Intra-urban differentials in child health: Health Transition Review, 5, 163190 www.toolingU.com 